Nadwa | Jurnal Pendidikan Islam

Vol. 11, Nomor 2 Tahun 2017

\title{
Peran Penting Psikologi Dalam Pendidikan Islam
}

\author{
Imam Anas Hadi \\ UNDARIS Semarang \\ imamhadianas309@gmail.com
}

\begin{abstract}
This study aims to determine the important role of psychology for Islamic education. The method used library research. Data collection uses documentation and data analysis with descriptive analysis. The results showed that psychology plays an important role in Islamic education as a religious consciousness associated with the values of the soul that is personality. In Islamic Psychology it is better known as term al-Syakhsiyah. The role of psychology in Islamic education is to bridge the delivery process of science to pay more attention to the psychology of each learner, this will determine success of the transfer process of values to students, becouse student and teacher have opened psychology and ready to make good communication. .
\end{abstract}

Keywords: Islamic Education, Psychology, personality

\begin{abstract}
Abstrak
Penelitian ini bertujuan untuk mengetahui peran penting psikologi bagi pendidikan Islam. Metode yang digunakan library research. Pengumpulan data menggunakan dokumentasi dan analisa data dengan analisis deskriptif. Hasil penelitian menunjukkan bahwa psikologi berperan penting dalam pendidikan Islam yaitu sebagai penanaman kesadaran keagamaan yang berhubungan dengan nilai-nilai bathiniyah yang bersifat pribadi (personality). Dalam istilah psikolgi Islam lebih dikenal dengan term al-Syakhsiyah. Peran psikologi dalam pendidikan Islam adalah menjembatani proses penyampaian ilmu pengetahuan agar lebih memperhatikan psikologi masing-masing peserta didik, hal ini akan sangat menentukan keberhasilan proses transfer of values siswa.
\end{abstract}

Kata Kunci: Pendidikan Islam, Psikologi, personality 


\section{Pendahuluan}

Pendidikan Islam adalah suatu proses penggalian, pembentukan, pendayagunaan, dan pengembangan fikir, zikir, dan kresi manusia, melalui pengajaran, bimbingan, latihan, dan pengabdian yang dilandasi dan dinafasi oleh nilai-nilai ajaran Islam, sehingga terbentuk pribadi muslim yang sejati, mampu mengontrol, mengatur, dan merasa kehidupan dilakukan sepanjang zaman dengan penuh tanggung jawab semata-mata untuk beribadah kepada Allah SWT. ${ }^{1}$

Arti psikologis secara singkat didefinisikan yaitu studi tentang tingkah laku dan hubungan antar manusia. Kelakuan seorang individu tidak saja terdiri atas perbuatan-perbuatan yang dapat dilihat akan tetapi adalah semua reaksi terhadap semua keadaan didalam dan pengaruh dari berbagai faktor lingkungan. Organisasi manusia adalah sangat kompleks, faktor-faktor lingkungan yang dapat mempengaruhi organisme meliputi seluruh manusia. Benda-benda, situasi dan kondisi yang merupakan dunia luar dari kehidupan individu. ${ }^{2}$

Pendidikan Islam dan psikologi tidak dapat di pisahkan, istilah kepribadian (personality) dalam study keislaman lebih dikenal dengan term al-Syakhsiyah. Syakhsiyah berasal dari kata Syakh yang berarti pribadi kata tersebut diberi ya' nisbath sehingga menjadi kata benda buatan (masdar Shina'y) Syakhsiyah yang berarti kepribadian. Dalam literatur keislaman, terutama pada khazanah klasik abad pertengahan, kata syakhsiyah (sebagai padanan dari kepribadian) kurang begitu kenal. Terdapat beberapa alasan mengapa term itu tidak dikenal. Pertama, dalam al-Qur'an dan as-Sunnah tidak ditemukan term syaksiyah, kecuali dalam beberapa hadits disebutkan term syakhsy yang berarti pribadi (person), bukan kepribadian (personality). Kedua, dalam khazanah Islam klasik, para filosuf atau sufi lebih akrab menggunakan istilah akhlaq. Penggunaan istilah ini karena ditopang oleh ayat al-Qur'an dan Hadits rasul. Ketiga, term syakhsiyah hakikatnya tidak dapat

1 Bawani, Imam, Cendikiawan Muslim dalam Perspektif pendidikan Islam, Surabaya: Bina Ilmu Offset,1991. hlm. 79

${ }^{2}$ Kasijan, Psikologi Pendidikan, Surabaya: Bina Ilmu, 1984, hlm.12 
mewakili nilai-nilai fundamental Islam untuk mengungkap suatu fenomena atau perilaku batiniyah manusia. Artinya term syakhsiyah yang lazim dipakai dalam term psikologi kepribadian barat eksistensinya lebih pada deskripsi karakter, sifat, atau perilaku unik individu, sementara term akhlaq lebih menekankan pada aspek penilaiannya terhadap baik buruk suatu tingkah laku. Syakhsiyah merupakan akhlaq yang didevaluasi (tidak dinilai baik buruknya), sementara akhlaq merupakan syakhsiyah yang dievaluasi. ${ }^{3}$

Dalam sejarah umat manusia senantiasa muncul para ahli fikir yang menonjol dan pengaruhnya besar sekali terhadap trend perkembangan masyarakat masing-masing. oleh karena mereka berhasil mengamati kondisi dan situasi kehidupan masyarakat antara lain, dari aspek-aspek psikologis yang dari padanya dicetuskan konsep-konsep pandangan serta pengarahan trends perkembangan masyarakat kearah keselamatan hidupnya, meskipun diantaranya ada yang berhasil dan diantaranya menemui ketidak-puasan. Bahkan para nabi seperti nabi Muhammad saw. dalam membimbing dan pengarahkan kehidupan umatnya senantiasa menandaskan diri pada faktorfaktor psikologis yang sesuai engan trend, kemajuan perkembangan masyarakat. Setiap ajaran wahyu yang diberikan kepadanya mengandung aspek-aspek psikologis yang berlaku pada masanya. Itulah sebabnya antara lain al-Qur'an tidak diturunkan dengan sekaligus dalam satu periode, melainkan sesuai dengan kondisi dan situasi dinamika perkembangan. Disamping itu cara menyampaikan wahyu kepada umat, nabi juga mendasarkan pada faktor psikologis baik secara individual maupun secara kelompok sosial dan sebagainya.

Penelitian ini terinspirasi dari permasalahan yang sekarang banyak bermunculan terkait dengan masalah pendidikan Islam. Pendidikan Islam yang notabene menghantarkan dan menyampikan nilai-nilai namun pendekatannya kurang memperhatikan psikologi. Oleh karenanya penelitian ini akan berusaha mengungkap peran psikologi dalam pendidikan Islam.

\footnotetext{
${ }^{3}$ Kasijan, Psikologi Pendidikan..., hlm.13
} 
Keadaan demikian merupakan suatu mekanisme yang perlu dikembangkan dalam masyarakat kita. ${ }^{4}$

\section{Pendidikan Islam}

Pendidikan adalah usaha sadar dan terencana untuk mewujudkan suasana belajar dan proses pembelajaran agar peserta didik secara aktif mengembangkan potensi dirinya untuk memiliki kekuatan spiritual keagamaaan, pengendalian diri, kepribadian, kecerdasan, akhlak mulia, serta ketrampilan atau karakter yang diperlukan dirinya, masyarakat, bangsa, dan Negara. ${ }^{5}$ Dengan demikian Pendidikan merupakan kata kunci untuk setiap manusia agar ia mendapatkan ilmu. Hanya dengan pendidikanlah ilmu akan didapat dan diserap dengan baik. Pendidikan juga merupakan metode pendekatan yang sesuai dengan fitrah manusia yang memiliki fase tahapan dalam pertumbuhan. Selanjutnya tujuan pendidikan berkaitan erat dengan tujuan hidup manusia, dan tujuan hidup ini pun berbeda-beda antara bangsa yang satu dengan yang lainnya. ${ }^{6}$

Pengertian pendidikan Islam adalah dapat dipahami bahwa hasil yang dicapai dari pendidikan tersebut untuk kemajuan peradaban manusia yang membawa kemakmuran dan kesejahteraan masyarakat secara sempurna (lahir dan batin, material, spititual, dan moral) sebagai pencerminan dari nilainilai ajaran Islam. Adapun dasar-dasar pendidikan Islam adalah al-Qur'an, sunah nabi Muhammad SAW, kata-kata sahabat, kemaslahatan umat, nilai-nilai dan adat istiadat masyarakat, dan hasil pemikiran para pemikir Islam. $^{7}$ Sedangkan Dasar Pendidikan Islam adalah:

1. Al-Qur'an, al-Qur'an merupakan sumber nilai yang absalute, yang eksistensinya, tidak mengalami perubahan walaupun intresprestasinya dimungkinkan, mengalami

4 Arifin, Psikologi Dan Beberapa Aspek Kehidupan Rohaniyah Manusia, Jakarta: Bulan Bintang, 1995, hlm. 12-13

5 Zuchdi, Darmiyati, Pendidikan Karakter dengan Pendekatan Komprehensif : Terintegrasi dalam Perkuliahan dan Pengembangan Kultur Universitas, Yogyakarta : UNY Press, 2010,hlm. 2-3

${ }^{6}$ Ratna Wilis. Dahar, , Teori Belajar dan Pembelajaran, Jakarta : Erlangga, 2006.hlm. 98

7 Muhaimin, Pemikiran Pendidikan Islam, Kajian Filosofis dan Karangka Dasar Oprasionalnya, Bandung : Triganda Karya, 1993, hlm. 145 
perubahan sesuai dengan konteks zaman, keadaan, dan tempat. Al-qur'an dapat menjadi dasar pendidikan Islam karena didalamnya memuat sejarah pendidikan, al-Qur'an merupakan normatif teoristis dalam pelaksanaan pendidikan Islam (QS. 21: 107).

2. Sunah nabi SAW, konsepsi dasar pendidikan yang dicetuskan dan dicontohkan nabi Muhammad SAW adalah sebagai berikut; disampaikan sebagai Rahmatan lil'alamin yang ruang lingkupnya tidak sebatas manusia tetapi juga lingkungan/makhluk biotik dan a biotik disampaikan secara universal, mencakup dimensi kehidupan apapun yang berguna bagi kegembiraan dan peringatan bagi umatnya (QS. 34: 28), apa yang disam paikan merupakan kebenaran yang mutlak (QS. 2: 119) dan keotentikan kebenaran itu terus terjadi (QS. 15: 9), kehadiran nabi sebagai evaluator yang mampu mengawasi dan terus bertanggung jawab atas aktifitas pendidikan (QS. 42: 48), perilaku nabi SAW tercermin sebagai uswatun hasanah (QS. 33: 21), masalah teknis praktis dalampelaksanaan pendidikan islam diserahkan penuh kepada umatnya.

3. Kemaslahatan masyarakat, maksudnya menetapkan peraturan yang tidak disebutkan dalam al-Qur'an dan asSunah atas pertimbangan penarikan kebaikan dan penolakan kerusakan dalam kehidupan masyarakat.

4. Nilai-nilai dan adat istiadat masyarakat, maksudnya suatu perbuatan dan perkataan yang menjadikan jiwa merasa tenang dalam mengerjakan sesuatu perbuatan, karena sejalan dengan akal dan diterima oleh tabiat yang sejahtera. Namun tidak semua nilai tradisi masyarakat dijadikan dasar ideal pendidikan Islam, dan dapat diterima setelah dieleksi terlebih dahulu.

5. Hasil pemikiran muslim (ijtijad), maksudnya upaya yang sungguh-sungguh dalam memperoleh hukum syara' berupa konsep operasional melalui metode istinbath (deduktif maupun induktif) dari al-Qur'an dan as-Sunah.

Tujuan pendidikan Islam dapat diklasifikasikan menjadi tiga bagian, yaitu tujuan akhir, tujuan umum, dan tujuan khusus. Tujuan akhir berkaitan dengan penciptaan manusia dimuka bumi oleh Allah SWT, yaitu membentuk pribadi muslim yang sejati, 
memiliki kedalaman keilmuan, ketajaman pemikiran, dan keluasan pandangan, kekuatan iman yang sempurna, serta kemampuan berkarya melalui kerja-kerja kemanusiaan dalam multi dimensi kehidupan, manusia-manusia yang sampai pada derajat didikan adalah sampai pada darajat ma'rifatullah yang diberi gelar khalifatullah fi al-'ard. Tujuan pendidikan umum pendidikan Islam adalah berkenaan dengan oprasionalisasi dari pribadi khalifatullah tersebut, yaitu menghindarkan segala belenggu yang bias menghambat pembentukan muslim sejati dan berusaha membentuk pribadi dengan mengembangkan berbagai fitrah (jasad, roh, pikiran, naluri, dan sebagainya) yang dimiliki manusia, dan diusahakan selama berada didalam lembaga pendidikan hingga mencapai kedewasaan dalam ukuran fikir, dzikir dan amal. Dan tujuan khusus pendidikan Islam berkenaan dengan penjabaran dari sebagian aspek-aspek pribadi khalifatullah yang hendak diusahakan melalui pemberian berbagai kegiatan tertentu dalam setiap pentahan proses pendidikan. $^{8}$

Dengan demikian hakekat pendidikan Islam adalah suatu proses pembentukan dan pengembangan fikir, dzikir dan kreasi manusia melalui bimbingan dan pengajaran yang dilandasi oleh nilai-nilai ajaran Islam al-Qur'an dan as-Sunnah sebagai dasarnya dengan tujuan untuk membentuk khalifatullah fil 'ardhi. Tugas dan Fungsi Pendidikan Islam senantiasa bersambung dan tanpa batas. Hal ini karena hakekat pendidikan Islam merupakan proses tanpa akhir sejalan dengan consensus universal yang ditetapkan oleh Allah SWT dan Rasul-Nya dengan istilah life long education. Menurut Hasan Langgulung tugas pendidikan Islam adalah sebagai berikut: (a) pendidikan dipandang sebagai pengembangan potensi, (b). pendidikan dipandang sebagai pewarisan budaya, (c). pendidikan dipandang sebagai interaksi antara potensi dan budaya. ${ }^{9}$ Tugas pendidikan agama Islam adalah membantu membina anak didik kepada ketaqwaan dan akhlaqul karimah yang dijabarkan dalam kompetensi yaitu keimanan, keislaman, dan multi aspek

8 Bawani, Imam, Cendikiawan Muslim dalam Perspektif pendidikan Islam, Surabaya: Bina Ilmu Offset, 1991. hlm. 19

9 Muhaimin, Pemikiran Pendidikan Islam, Kajian Filosofis dan Karangka Dasar Oprasionalnya, Bandung : Triganda Karya, 1993. hlm. 138 
keihsanan. Selain itu juga tugas pendidikan Islam mempertinggi kecerdasan dan kemampuan dalam memajukan ilmu pengetahuan dan teknologi, beserta manfaat dan aplikasinya dan dapat meningkatkan kualitas hidup dengan memelihara, mengembangkan, serta meningkatkan kualitas hidup dengan memelihara, mengembangkan, serta meningkatkan budaya hidup. ${ }^{10}$ Adapun fungsi pendidikan Islam adalah menyediakan segala aktifitas yang dapat memungkinkan tugas pendidikan Islam tersebut dapat tercapai dan berjalan dengan lancar.

\section{Psikologi}

Ditinjau dari ilmu bahasa, perkataan psikologi ini berasal dari perkataan Psiche yang diartikan jiwa dan perkataan logos yang berarti ilmu atau ilmu pengetahuan. Karena itu perkataan psikologi sering diartikan atau diterkjemahkan dengan ilmu pengatahuan tentang jiwa atau disingkat dengan ilmu jiwa. ${ }^{11}$

Namun demikian sementara ahli ada yang kurang berpendapat bahwa pengertian psikologi itu benar-benar sama dengan ilmu jiwa, walaupun ditinjau dari arti kata kedua istilah itu sama. Hal ini sesuai yang dikemukakan oleh Gerungan didalam buku yang berjudul pengantar psikologi umum yang dikarang oleh Bimo Walgito. Menurut Gerungan arti kata kedua istilah itu menurut isinya sebenarnya sama, sebab kata psychology itu mengandung kata psyche, yang dalam bahasa Yunani berarti jiwa dan kata logos dapat diterjemahkan dengan kata ilmu, sehingga istilah ilmu jiwa itu merupakan terjemahan belaka dari pada istilah psychology. Walaupun demikian, namun kami pergunakan kedua istilah berganti-ganti. dan dengan kesadaran adanya perbedaan yang jelas dalam artinya yaitu:

1. Ilmu jiwa itu merupakan istilah bahasa Indonesia sehari-hari dan yang dikenal tiap-tiap orang, sehingga kamipun menggunakan dalam artinya yang luas dan lazim dipahami orang. Sedangkan kata psychology itu merupakan suatu istilah ilmu pengetahuan suatu istilah yang scientifle,

\footnotetext{
${ }^{10}$ Bawani, Imam, Cendikiawan Muslim ..

11 Walgito, Bimo, Pengantar Psikologi Umum, Yogyakarta: Yayasan penerbitan fakultas psikologi UGM, 1985. hlm.7
} 
sehingga kami pergunakan untuk menunjukkan kepada pengetahuan ilmu jiwa yang bercorak ilmiah tertentu.

2. Ilmu jiwa kami pergunakan dalam arti yang lebih luas dari pada istilah psychology, ilmu jiwa meliputi segala pemikiran, pengetahuan, tanggapan, tetapi juga segala jalan dan spikulasi mengenai jiwa itu. Psychology mengenai ilmu pengetahuan mengenai jiwa yang diperoleh secara sistematis, dengan metode-metode ilmiah memenuhi syarat-syarat yang dimufakati oleh sarjana-sarjana psikologi. Istilah ilmu jiwa menunjukkan pada ilmu jiwa pada umumnya, sedangkan psychology menunjukkan ilmu jiwa yang ilmiah menurut norma-norma imiah modern. Dengan demiakian cukup jelas bahwa apa saja yang disebut ilmu jiwa itu belum tentu psychology, tetapi psychology ini senantiasa juga ilmu jiwa. ${ }^{12}$

Menurut Arifin dalam bukunya yang berjudul Psikologi Dan Beberapa Aspek Kehidupan Rohaniyah Manusia, mengatakan bahwa pengertian psikologi secara lafdhiyyah adalah terdapat kesamaan psikologi diartikan sebagai ilmu jiwa atau ilmu pengetahuan tentang jiwa, oleh karena itu psikologi berasal dari kata psyche yang artinya jiwa dan logos yang artinya ilmu. Dan ilmu psikologi sebagai ilmu pengetahuan sebagai mana Allah SWT berfirman:

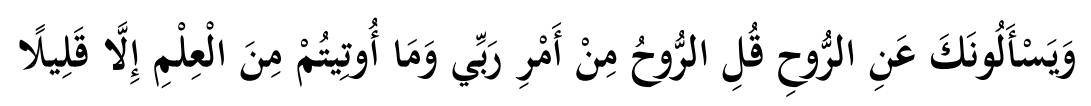

$(\wedge \Delta)$

Mereka menanyakan kepadamu tentang jiwa, maka katakanlah bahwa jiwa itu adalah urusan Tuhanku dan kamu tidak diberu ilmu (tentang jiwa itu) kecuali sedikit saja (QS. al-Isra': 85).

Manusia diciptakan Tuhan terdiri dari dua aspek kehidupan yaitu aspek jasmaniyah dan aspek rohaniyah, aspek fisik/materiil dan mental/spiritual atau fisiologis dan psikologis. Kedua aspek kehidupan tersebut menjadi onyek penelitian yang menarik, perhatian para ahli ilmu pengetahuan sosial dan kaalaman sampai pada zaman modern sekarang, oleh karena

${ }^{12}$ Walgito, Bimo, Pengantar Psikologi.... hlm. 7-8 
didalamnya terkandung rahasia yang sangat berharga yang perlu diketahui untuk kebahagiaan hidup manusia sendiri. ${ }^{13}$

Penyelidikan terhadap aspek-aspek kehidupan jasmaniyah, misalnya telah menelorkannya berbagai ilmu pengetahuan seperti ilmu fisiologi, biologi, anatomi, ilmu kesehatan, dansebagainya, sedangkan penyelidikan terhadap aspek-aspek rohaniyahnya menimbulkan berbagai keilmuan seperti ilmu psikologi, sosiologi, antropologi dan sebagainya. Akan tetapi bila dilihat dari segi kemungkinan ketepatan dalam penyelidikan, maka ilmu psikologi merupakan ilmu pengetahuan yang paling sulit untuk menemukan ketepatan tersebut, oleh karena obyeknya adalah jiwa, sesuatu kekuatan yang abstrak serta tidak bisa dilihat oleh pancaindra tentang wujud dan zatnya, melainkan yang tampak adalah hanya gejala saja. Dan gejala ini yang mungkin dapat dijadikan sasaran penyelidikan ilmu jiwa (psikologi) tersebut. ${ }^{14}$ Menurut Kartono pengertian psikologi atau ilmu jiwa adalah ilmu yang mempelajari tingkah laku dan gejala-gejala kejiwaan manusia. ${ }^{15}$

Menurut Sumardi Subroto psikologi dapat dikatagorikan kedalam dua macam, yaitu:

1. Psikolog spikulatif, yaitu psikolog yang menyusun teoriteorinya atas pemikiran spikulatif, seperti Plato, Kant, ahliahli dari aliran neo kontianisme, Bahnsen, Queyrat, Malapert, dan lain-lain lagi. Mereka adalah para ahli Filsafat.

2. Psikologi Empiris atau psikolog eksperimental, yaitu psikolog yang menyusun teori-teorinya atas dasar data-data dari hasil penyelidikan atau eksperimen, seperti Watson, Jung, Adler, Eysenk, Rogers, dan lain-lain ${ }^{16}$.

\section{Psikologi dalam Islam}

Kepribadian dalam bahasa Inggris disebut juga dengan personality. Akar kata personality berasal dari bahasa latin persona yang berarti topeng Yaitu topeng yang dipakai oleh

13 Arifin, Psikologi dan Beberapa Aspek Kehidupan Rohaniyah Manusia, Jakarta: Bulan Bintang, 1995. hlm. 17

${ }^{14}$ Arifin, Psikologi dan Beberapa ...hlm. 17-18

${ }^{15}$ Kartono, Kartini, Psikologi sosial untuk manajemen perusahaan dan industri, Jakarta: PT RajaGrafindo Persada, 1987, hlm. 1

16 Broto, Sumardi Surya, , Psikologi Kepribadian, Jakarta: PT. Raja Grafindo Persada, Cet. VII, 1995. hlm. 4-5 
aktor drama atau sandiwara. Atau juga dari bahasa latin personare yang berarti to sound trough (suara tembus). ${ }^{17}$ Seorang aktor Yunani kuno telah terbiasa memekai topeng (pesona) ketika memerankan tokoh dalam suatu drama. Tujuan pemakaian topeng ini melainkan untuk menyembunyikan identitas. Juga untuk kekeluasaan dalam memerankann sosok pribadi lain. Tekhnik drama ini kemudian diambil alih oleh bangsa Roma dengan istilah pearsonality. Bagi bangsa Roma persona semula diartikan tentang bagaimana seseorang tampak pada orang lain dan bukan pribadi yang sesungguhnya. Aktor menciptakan dalam pikiran penonton satu kesan (impression) dari tokoh yang diperankan diatas panggung, bukan kesan dari pribadi aktor sendiri. Berdasarkan pemahaman ini maksud dari personality bukanlah suatu atribut yang pasti dan spesifik, melainkan suatu kualitas perilaku total seseorang. ${ }^{18}$

Istilah kepribadian sering dijumpai dalam beberapa riteratur dengan berbagai ragam makna dan pendekatan. Sebagian Psikolog ada yang menyebutkan dengan pertama, Personality (kepribadian) sendiri. Sedang ilmu yang membahas disebut dengan The Psycology of Personality atau Theory of Personality, kedua, Character (watak atau perangai), sedangkan ilmu yang membicarakan disebut dengan The Psycology of Character, atau Caracterology, ketiga, Type (tipe), sedang ilmu yang membahasnya disebut Typology. ${ }^{19}$ Ketiga istilah tersebut yang dipakai adalah istilah kepribadian. Selain ruang lingkupnya jelas, istilah kepribadian juga mencerminkan konsep keunikan diri seseorang.

Sumardi Suryobroto menyatakan bahwa karakter itu sama dengan kepribadian, tetapi dipandang dari sudut yang berlainan. Istilah karakter dipandang dari sudut penilaian baik buruk senang benci menerima menolak suatu tingkah laku berdasarkan norma-norma yang dianut. Sedangkan istilah kepribadian

17 Lester, D. Crow and Alice Crow, Terj. A. Karijan, Psikologi Pendidikan, Surabaya: Bina Ilmu, 1984. hlm. 262

${ }^{18}$ Elizabeth, B.hurlock, , Child Development, New York: McGrow Hill, 1978. hlm. 524

19 Subroto, Sumardi, , Psikologi kepribadian, Jakarta: Rajawali, 1990.hlm. 1 
dipandang dari sudut penggambaran manusia apa adanya tanpa disertai penilaian. ${ }^{20}$

Karakter dapat dikatakan sebagai kepribadian yang dievaluasi, sedangkan kepribadian adalah karakter yang dievaluasi. Melalui perbedaan sudut pandang ini tampak jelas bahwa psikologi kepribadian yang berkembang dewasa ini berbeda dengan ilmu akhlak dalam wacana keilmuan Islam. Psikologi kepribadian membicarakan tentang tingkah laku manusia menurut apa adanya dan bukan bagaimana seharusnya. Tujuan penggambaran tingkah laku ini adalah untuk mengetahui, menentukan dan mengkatagorikan sifat-sifat dan tipologi-tipologi khas individu dan aspek-aspek kejiwaan tertentu yang menentukan sifat dan tipologinya. Istilah tipologi juga tidak bisa diidentikkan dengan istilah kepribadian, sebab ruang lingkupnya sangat sempit. Tipologi merupakan salah satu pendekatan psikologi kepribadian yang berdasarkan atas tipetipe manusia tertentu, padahal dalam psikologi kepribadian masih terdapat pendekatan lain yang sering digunakan, seperti pendekatan penyifatan. Personality berasal dari kata person yang secara bahasa memiliki arti pertama, an individual human being (sosok manusia individu), kedua, a cammon individual (individu secara umum), ketiga, aliving human body (orang yang hidup), keempat, self (pribadi), kelima personal existence or identity (keberadaan dan identitas pribadi), keenam, distinctive personal character (watak individu tertentu). ${ }^{21}$

Definisi etimologi dari sudut historisnya mempunyai beberapa arti. Allport mengidentifikasikannya dengan perwujudan lahiriah, watak atau peran yang diperankan sebuah drama, sifat-sifat khusus yang dimiliki seseorang pestise dan martabat, warga negara yang bebas bukan (budak), seorang wakil yang mewakili kelompok atau lembaganya. ${ }^{22}$

Para psikologi sendiri, khususnya dari kalangan barat, yang terakumulasi dalam tiga aliran besar, telah banyak

${ }^{20}$ Prodjo, W. Poespo , Filsafat Moral, Kesusilaan dalam Teori dan Praktek, Bandung: Remadja Karya, 1986. hlm. 8

${ }^{21}$ Noah, Webster, Webs'ter New Twentieth Century Dictionary of the English LanguageUnabridged, New York: William Collins Publishers, 1980. hlm. 138

22 Patty F, dkk, , Pengantar Psikologi Umum, Surabaya: Usaha Nasional, 1982. hlm. 144 
menyumbangkan teori-teori tentang kejiwaan manusia. Teoriteori tersebut diantaranya meliputi teori kepribadian, perkembangan, fungsi-fungsi psikis manusia, dan lain-lain. Teori-teori tersebut banyak dipakai akademis dan bahkan menjadi rujukan bagi para psikolog sesudahnya. Permasalahan kemudian adalah apakah semua teori itu dapat diterima dalam Islam? Pertanyaan itu muncul karena paradigma atau pola pikir yang mereka gunakan untuk membuat teori tersebut berbeda dengan paradigma atau pola pikir yang mereka gunakan dalam Islam. Psikologi barat dilandasi oleh nilai-nilai sosial budaya yang sangat rasional dan sekular. Ini tampak dari corak psikologi yang orientasi filasafahnya adalah antroposentris serta hanya mengakui unsur-unsur ragawi (organa-biologis) kejiwaan (psiko edukasi) dan lingkungan (sosio-kultural) sebagai penentu utama kepribadian dan perilaku.

Bagi aliran psikoanalisa, manusia dipandang sebagai makhluk yang tidak sehat mental. Maslow mengatakan bahwa Freud seakan-akan memasok kita dengan separo psikologi yang sakit. Psikoanalisa juga berfokus pada insting-insting hewani dan memahami manusia dari perilaku pasiennya. Elmira mengatakan bahwa psikoanalisa menekankan pada faktor insting seksual sebagai faktor utama yang menentukan perkembangan manusia. Perkembangan manusia dianggap dibentuk oleh berbagai jenis pengalaman masa kanak-kanak awal. Teori-teori tersebut jelas bertentangan dengan konsep Islam. Islam mengatakan bahwa manusia diciptakan dan dilahirkan dalam kesucian dan kefitrahan tidak membawa dosa dan kesalahan. Juga Islam memiliki pedoman dan ajaran yang lebih agung daripada sekadar libido. ${ }^{23}$

Aliran Humanistik muncul pada pertengahan abad kedua puluh sebagai reaksi terhadap kedua aliran diatas. Humanistik memandang manusia sebagai makhluk yang bebas dalam menentukan perkembangan dirinya menjadi manusia yang sehat mental apabila ia mendapat kesempatan, sehingga ia dapat perilaku optimal sesuai dengan potensi yang dimilikinya. Manusia dianggap sebagai makhluk bermartabat dan bertanggung jawab, yang memiliki beberapa potensi-potensi yang perlu diusahakan pengaktualisasiannya. Tujuan terakhir

\footnotetext{
${ }^{23}$ Patty F, dkk, , Pengantar ..., 145
} 
adalah agar individu dapat mengembangkan kemanusiannya secara penuh. ${ }^{24}$

Aliran humanistik mencoba untuk memanusiakan manusia. Namun pemanusiaan itu telah melewati fitrah kemanusiaan. Pandangan humanistik sangat optimistis dan bahkan terlampaui optimistis terhadap upaya pengembangan sumber daya manusia, sehingga manusia dipandang sebagai penentu tunggal yang mampu melakukan Play God. ${ }^{25}$ Aliran humanistik menganggap manusia mampu menyelesaikan segala permasalahannya sendiri, padahal manusia mempunyai kekurangan dan kelemahan, dan serba keterbatasan sehingga ia tidak bisa lepas dari Zat Yang Maha Kuasa Sang Maha Pengatur. ${ }^{26}$

Dengan orientasi seperti ini manusia ditempatkan pada posisi yang teramat tinggi. Ia adalah pusat dari segala pengalaman dan relasi-relasi dengan dunianya serta penentu utama nasibnya sendiri dan nasib orang lain seperti yang diyakini oleh para psikolog humanistik dan transpersonal. Dalam posisi serupa ini, manusia seakan-akan menjadi prima causa dari semua peristiwa yang menyangkut manusia dan kehidupannya. Antroposentrisme dan determinan tridimensional raga-jiwa-lingkungan perlu diterima dengan sikap kritis dan waspada, karena pada tingkat ekstrim pandangan itu selain memberi peluang kepada manusia untuk berperan sebagai penentu tunggal yang mampu melakukan segalanya secara implisit tentu dengan mengabaikan kuasa dan kehendak Tuhan, juga mengabaikan unsur ruh sebagai dimensi khusus insani yang merupakan sarana ghaib untuk menerima petunjuk dan bimbingan-Nya. ${ }^{27}$

Ketidakpuasan pada teori psikologis barat ini menyebabkan banyak para psikolog muslim tergerak untuk memunculkan psikologi alternatif sebagai aliran baru dalam dunia psikilogi, yaitu psikologi Islami, psikologi yang memiliki paradigma Islami sesuai dengan al-Qur'an dan as-Sunnah. Mereka

${ }^{24}$ Rendra, Metodologi Psikologi Islam, Yogyakarta: Pustaka Pelajar, 2000. hlm. 40

25 Ancok, Djamaludin, Psikologi Islam Solusi Islam atas Problem-Problem Psikologi, Yogyakarta: Pustaka Pelajar, 1994. hlm. 83

${ }^{26}$ Ancok, Djamaludin, Psikologi ..

27 Hanna, dhumhana Bastaman, , Integrasi Psikologi dan Islam, Yogyakarta: Pustaka Pelajar, 1995. hlm. 222 
meyakini bahwa Islam telah memberikan pedoman bagi manusia secara lengkap dan paripurna, juga Islam tidak hanya menerima pemikiran dan teori-teori psikologi dari barat begitu saja, tetapi dalam Islam ada filterisasi pemikiran dan teori barat yang cenderung antroposentris. Islam memiliki paradigma sendiri yang unik, meskipun demikian dalam hal-hal tertentu, Islam sangat terbuka terhadap pemikiran dan teori mereka. Oleh karena itu, dibutuhkan sebuah rujukan yang lebih damai tanpa memberikan label Islam terhadap psikologinya, tetapi justru memuat sebuah wacana yang integratif dan penuh dengan nuansa Islami. ${ }^{28}$

\section{Penggunaan Psikologi dalam Proses Pendidikan Islam}

Sesungguhnya pandangan al-Qur'an terhadap manusia adalah pandangan yang menyeluruh, terpadu, seimbang dan tepat. Manusia bukan hanya berupa wujud materi yang terdiri dari fisika, fisika, kimia, dan otot-otot mekanis, sebagaimana pandangan filosof-filosof materialistis. Manusia juga bukan hanya roh yang terlepas dari raga sebagaimana pendapat sebagian kaum terpelajar. Manusia menurut al-Qur'an adalah terdiri dari jiwa dan raga yang keduanya saling berhubungan dan saling mempengaruhi. Manusia bukanlah binatang yang akan habis riwayatnya dan lenyap hidupnya setelah mati dan bukanlah binatang yang wujudnya tidak berbeda dengan binatang-binatang lain. Manusia bukan juga makhluk yang paling tinggi yang tidak ada sesuatu diatasnya. Namun manusia mempunyai keutamaan, kelebihan, kemuliaan dan kedudukan yang tinggi dengan notabene apabila tahu diri, berilmu dan mahu menggunakan akalnya. Apabila ia jatuh meluncur ketingkat yang paling rendah jelek, maka hilanglah kemanusiaannya dan ia berkedudukan yang paling hina daripada binatang. ${ }^{29}$

Proses tranmisi pengaruh sosial kedalam diri individu melalui dua cara, yaitu cara formal dan informal, pengetahuan dan ketrampilan dipelajari oleh individu melalui proses belajar

\footnotetext{
${ }^{28}$ Hanna, dhumhana Bastaman, , Integrasi ...,

29 Barnadjib, Imam, Filsafat Pendidikan,Yogyakarta: Fakultas Ilmu Pendidikan FIP, 1987. hlm. 4
} 
formal atau sistematik. Hasil belajar formal itu nampak dalam tingkah laku ferbal dan tercermin pada apa yang dipikirkannya. Nilai dan pola tingkah laku dipelajari oleh individu melalui proses belajar informal, yaitu proses imitasi (yang sebagian tidak didasarinya) dalam kontaknya dengan orang-orang yang berkewibawaan. Para ahli berpendapat bahwa cara hidup masyarakat itu meresapnya kedalam diri individu terjadi pada awal perkembangan kepribadiannya melalui hubungan dengan orang-orang dewasa, khususnya orang tua. Diinternalisasi kedalam diri anak dan secara tidak sadar menjadi bagian dirinya. Proses internalisasi itu kadang-kadang juga disebut juga dengan istilah akulturasi, introjeksi, atau sosialisasi. Corak hubungan orang tua dan anak sangat menentukan proses sosialisasi anak, corak hubungan dengan orang tua dengan anak ini, berdasarkan penelitian yang dilakukan oleh Fels research institute, dapat dibedakan menjadi tiga pola yaitu: Pertama, pola menerima menolak, pola ini didasarkan atas taraf kemesraan orang tua terhadap anak. Kedua, pola memiliki melepaskan, pola ini berdasarkan atas seberapa besar sikap protektif orang tua terhadap anak. Pola ini bergerak dari sikap orang tua yang overprotektif dan memiliki anak sampai pada sikap mengabaikan anak sama sekali. Ketiga, pola demokrasi otokrasi, pola ini didasarkan atas taraf partisipasi anak dalam menentukan kegiatan-kegiatan dalam keluarga. Pola otokrasi berarti orang tua bergerak sebagai didaktor terhadap anak, sedangkan dalam pola demokrasi, sampai batas-batas tertentu, anak dapat dipartisipasi dalam keputusan-keputusan keluarga. ${ }^{30}$

Dalam lembaga formal yang sangat kompeten terhadap anak adalah seorang guru karena hal ini ikut menentukan keberhasilan. Tugas guru adalah keterbukaan kejiwaan guru itu sendiri. Keterbukaan ini merupakan dasar kompetensi profesional (kemampuan dan kewenangan melaksanakan tugas) keguruan yang harus dimiliki oleh seorang guru. Guru yang terbuka secara psikologis biasanya ditandai dengan kesediaannya yang relatif tinggi untuk mengkomunikasikan dirinya dengan faktor-faktor eksternal antara lain siswa, teman sejawat lingkungan pendidikan tempat bekerja. Ia mahu

30 Vembriarto, , Sosiologi Pendidikan, Yogyakarta: Andi Offset, 1990. hlm. 50-51 
menerima kritik dengan ikhlas. Di samping itu ia juga memiliki empati, yakni respon efektif terhadap pengalaman emosional dan perasaan tertentu terhadap orang lain. Jika salah seorang muridnya diketahui sedang mengalami kemalangan, umpamanya, maka ia ikut bersedih dan menunjukkan simpati serta berusaha memberi jalan keluar.

Keterbukaan psikologis sangat penting bagi seorang guru mengingat pasisinya sebagai panutan siswa. Selain sisi positif yang dimiliki oleh seorang guru dalam keterbukaan psikologis yaitu: Pertama, keterbukaan psikologis merupakan pra kondisi atau persyaratan penting yang harus dimiliki guru untuk memahami pikiran dan perasaan orang lain. Kedua, keterbukaan psikologis diperlukan untuk menciptakan suasana hubungan antar pribadi guru dan siswa yang harmonis, sehingga mendorong siswa untuk mengembangkan dirinya secara bebas dan tanpa ganjalan. ${ }^{31}$ Ketika terjadi komunikasi psikologis inilah seorang guru telah membangun saling percaya kepada siswanya sehingga siswa secara psikologis akan membuka diri terhadap informasi dan komunikasi yang baru yang akan dapat merubah pola fikir dan pola prilakunya. Dengan demikian proses pendidikan akan semakin menemukan bentuknya dan dapat mencapai tujuan pembelajaran dengan baik.

\section{Penutup}

Berdasarkan paparan dan pembahasan di atas, penulis dapat menyimpulkan bahwa Pendidikan Islam pada haikikatnya adalah suatu proses penggalian, pembentukan, pendayagunaan, dan pengembangan fikir, zikir, dan kresi manusia, melalui pengajaran, bimbingan, latihan, dan pengabdian yang dilandasi oleh nilai-nilai ajaran Islam, sehingga terbentuk pribadi muslim yang sejati. Peran psikologi dalam pendidikan Islam sebagai menjembatan proses penyampaian ilmu pengetahuan agar lebih efektif sesuai dengan kematangan psikologi masing-masing peserta didik dan kesediaan peserta didik untuk membuka diri terhadap informasi dan pengetahuan baru serta kesediaan menggunakannya dalam kehidupan sehari-hari. Dengan memperhatikan psikologi siswa dari para guru kepada siswa

31 Syah, Muhibbin, Psikologi Pendidikan, Bandung: PT. Remaja Rosdakarya Offset, 1995. hlm. 228 
akan sangat menentukan keberhasilan proses tansfer nilai-nilai serta karakter pada peserta didik.

\section{Daftar Pustaka}

Ancok, Djamaludin, 1994, Psikologi Islam Solusi Islam atas Problem-Problem Psikologi, Yogyakarta: Pustaka Pelajar.

Arifin, Psikologi Dan Beberapa Aspek Kehidupan Rohaniyah Manusia, Jakarta: Bulan Bintang

Barnadjib, Imam, 1987, Filsafat Pendidikan,Yogyakarta: Fakultas Ilmu Pendidikan FIP

Bawani, Imam, 1991, Cendikiawan Muslim dalam Perspektif pendidikan Islam, Surabaya: Bina Ilmu Offset

Broto, Sumardi Surya , 1995, Psikologi Kepribadian, Jakarta: PT. Raja Grafindo Persada, Cet. VII

Choplin,1999, Kamus lengkap Psikologi, Jakarta: Raja grafindo Persada, Cet. V

Depag RI, 2004, Al-Qur'an dan Terjemahannya, Bandung: Diponegoro

Elizabeth, B.hurlock, 1978, Child Development, New York: McGrow Hill

Elizabeth, B.hurlock, 1988, Perkembangan Anak, Jakarta: Erlangga

Hanna, dhumhana Bastaman, 1995, Integrasi Psikologi dan Islam, Yogyakarta: Pustaka Pelajar

Kartono, Kartini, Psikologi sosial untuk manajemen perusahaan dan industri, Jakarta: PT RajaGrafindo Persada

Kasijan, 1984, Psikologi Pendidikan, Surabaya: Bina Ilmu

Lester, D. Crow and Alice Crow, Terj. A. Karijan, 1984, Psikologi Pendidikan, Surabaya: Bina Ilmu

Muhaimin, 1993, Pemikiran Pendidikan Islam, Kajian Filosofis dan Karangka Dasar Oprasionalnya, Bandung : Triganda Karya

Mujib, Abdul, Dkk, 2002, Nuansa-Nuansa Psikologi Islam, Jakarta: Raja GrafindoPersada

Munjib, Abdul dan Mundzakir Yusuf, 2001, Nuansa-nuansa Psikologi Islam, Jakarta: Rajawali Pers 
Noah, Webster, 1980, Webs'ter New Twentieth Century Dictionary of the English LanguageUnabridged, New York: William Collins Publishers

Patty F, dkk, 1982, Pengantar Psikologi Umum, Surabaya: Usaha Nasional

Prodjo, W. Poespo , 1986, Filsafat Moral, Kesusilaan dalam Teori dan Praktek, Bandung: Remadja Karya

Ratna Wilis. Dahar, 2006, Teori Belajar dan Pembelajaran, Jakarta : Erlangga

Rendra, 2000, Metodologi Psikologi Islam, Yogyakarta: Pustaka Pelajar

Sarlito Wirawan, Sarwono, 1991, Berkenalan dengan Aliranaliran dan Tokoh-Tokoh Psikologi, Jakarta: Bulan Bintang, Cet. III

Shaleh, Abdul Rahman, 2008, Psikologi Suatu Pengantar dalam Perspektif Islam, Jakarta: Kencana.

Subroto, Sumardi, 1990, Psikologi kepribadian, Jakarta: Rajawali

Syah, Muhibbin, 1995, Psikologi Pendidikan, Bandung: PT. Remaja Rosdakarya Offset

Taufiq, Muhammad Izzudin, 2006, Panduan Lengkap dan Praktis Panduan Psikologi Islam, Depok: Gema Insani.

Tim Penembangan MKDK, 1989, Psikologi Belajar, Semarang: IKIP Semarang Press

Vembriarto, 1990, Sosiologi Pendidikan, Yogyakarta: Andi Offset

Walgito, Bimo, Pengantar Psikologi Umum, Yogyakarta: Yayasan penerbitan fakultas psikologi UGM

Yadi, Purwanto, 2007, Epistimologi Psikologi Islami Dialektika PendahuluanPsikologi Barat dengan Psikologi Islam, Bandung: Refika Aditama.

Zuchdi, Darmiyati, 2010, Pendidikan Karakter dengan Pendekatan Komprehensif : Terintegrasi dalam Perkuliahan dan Pengembangan Kultur Universitas, Yogyakarta : UNY Press 